\title{
Stakeholders' Views on Management Arrangements: A Case of Kingfish Fishery in the Sultanate of Oman
}

\author{
Abdullah Hilal Al-Balushi', Shekar Bose ${ }^{2}$, Anesh Govender ${ }^{3}$ \\ ${ }^{1}$ Oman Animal and Plant Genetic Resources Center, The Research Council, Muscat, Oman \\ ${ }^{2}$ Department of Natural Resource Economics, College of Agricultural and Marine Sciences, Sultan Qaboos \\ University, Muscat, Oman \\ ${ }^{3}$ Department of Marine Science and Fisheries, College of Agricultural and Marine Sciences, Sultan Qaboos \\ University, Muscat, Oman \\ Email: Sbose@squ.edu.om
}

Received 22 March 2016; accepted 20 May 2016; published 23 May 2016

Copyright (C) 2016 by authors and Scientific Research Publishing Inc.

This work is licensed under the Creative Commons Attribution International License (CC BY).

http://creativecommons.org/licenses/by/4.0/

c) (i) Open Access

\begin{abstract}
This paper exemplifies a primary step towards eliciting primary and secondary stakeholders' views on management issues pertaining to kingfish fishery in Oman, and potential options for effective management of the fishery using questionnaire surveys and focus group interviews. There was consensus from stakeholder groups which included fishers, fishery managers, and fishery scientists that the current stock condition is not biologically sustainable. It is found that fishing effort control and technical measures are preferred to catch control by both groups. The role of mass media and the traditional institution in communicating fisheries issues are found to be relatively minor. Although the overall rating on the comprehensiveness of the proposed plan is promising, there are significant differences between the two groups with regard to legislative arrangements $\left(\chi^{2}=24.793, p\right.$-value $\left.=0.000\right)$, management goals $\left(\chi^{2}=16.206\right.$, $p$-value $\left.=0.001\right)$, operational objectives $\left(\chi^{2}=19.884, p\right.$-value $\left.=0.000\right)$, performance indicators $\chi^{2}=15.524, p$-value $=$ $0.001)$, and measures $\left(\chi^{2}=13.483, p\right.$-value $\left.=0.004\right)$. Policy implications of the key findings are discussed in both national and regional contexts. Management authorities can use these findings to design an appropriate plan of actions for achieving sustainability in this fishery.
\end{abstract}

\section{Keywords}

Sustainability, Kingfish Fishery, Stakeholder Views, Management Arrangements, Oman 


\section{Introduction}

In the Sultanate of Oman, the fisheries sector is at the core of the economic development agenda, and accordingly the sector is expected to play a vital role in the enhancement of the country's socio-economic welfare, including food security [1]-[3]. In this context, progress towards the achievement of long-term sustainability in the fisheries sector is of paramount importance. Although the development plan for the sector projected average annual growth of 5.6\% by 2020 [2], high-value fish species such as kingfish (Scomberomorus commerson) have been experiencing a prolonged period of high fishing pressure. For instance, landings of kingfish have indicated a marked reduction (about 8.2\% per annum) during the period 1988-2011. The decline in landings has caused legitimate concern among policy makers, scientists, and fishers about its possible socio-economic consequences. Further reasons for considering kingfish fishery are as follows: firstly, kingfish is one of the most popular species in the traditional diet of the Omani people and the fishery provides significant employment and income opportunities to the traditional fishing community in Oman; secondly, a considerable amount of scientific research has already been conducted on this species in Oman and the information generated through these research activities is of particular use in developing operational objectives with appropriate indicators and management options; last but not least, the shared and migratory nature of kingfish stocks.

The overexploited status of the fishery has been documented in several local studies [4]-[10]. The poor state of kingfish species is also echoed in regional studies [11]-[13]. For instance, based on the analysis of length frequency data collected during January 2004-December 2006 for six Gulf Cooperation Council (GCC) countries under the GCC Kingfish Monitoring Program it was mentioned, among others, that i) the kingfish resource was overexploited; ii) a large proportion of (range: $42.19 \%$ to $81.31 \%$ ) immature fish were observed in the landed catch; iii) the average length of fish caught was more than the length of first maturity, and iv) the average annual yield (15,455 ton) was higher than the estimated maximum sustainable yield (MSY) of 14,711 tons for GCC countries [13].

Considering the overexploited status of the fishery and recognizing the international obligations stipulated in the 1982 United Nations Convention on the Law of the Sea (UNCLOS) [14] and the 1995 UN Fish Stocks Agreement [15] in relation to the conservation and management of "shared fish stocks", there is a persuasive call for introducing appropriate management arrangements by involving key stakeholders for maintaining long-term sustainability of the fishery [11] [13] [16]. In response to this call and with the purpose of promoting equity, legitimacy, and efficiency — the basic tenets of sustainable development [17]—-the main objective of the paper is to elicit primary and secondary stakeholders' views on the key issues pertaining to the effective management of the fishery in Oman. This type of participatory approach not only helps broaden decision makers' understanding of stakeholders' perceptions and attitudes, but also provides the basis for improved management through knowledge integration [18] [19], fosters cooperation through the development of mutual respect [20], and promotes regulatory effectiveness by reducing the extent of non-compliance [21] [22].

As the scope of the present study is limited to Oman, a legitimate question can be raised that in the case of a shared stock, views of a limited number of stakeholders in one country would not be sufficient to capture the preferences of the regional stakeholders. Although views elicited are limited in scope, the information presented in this study has contributed to the improvement of cooperative arrangements among the Gulf Cooperation Council (GCC) countries in relation to the conservation and management of kingfish resource. Evidence in support to this claim is presented in section 5 of the present study.

The objective of this paper is achieved in two steps. First, following the literature a simple objective-driven management plan for the fishery was drafted that encompassed the key dimensions of sustainable development [23]. Second, the plan was communicated with the primary (i.e. fishers) and secondary (i.e. fishery managers and scientists) stakeholders with the purpose of eliciting their views and preferences, and obtaining their evaluations. According to behavior literature (for instance, [24]), the formation of individual attitudes is likely to be influenced by factors such as personal experience (in the present case, gained through involvement in the fishery), information acquired from peers and exposure to mass media, and so on. On the other hand, the formation of individual perceptions is likely to be influenced by personal expectation from the fishery, individual needs and motives, and past experience, etc. Collectively, these factors are likely to exert influence on the personal evaluation of the fishery. Therefore, where relevant, an appropriate statistical test was conducted to determine whether response patterns were similar across groups.

The remainder of the paper is organized as follows. Section 2 provides an overview of the kingfish fishery in Oman along with its key characteristics. Section 3 describes, in detail, the methodology followed in preparing 
the plan. It also presents the stakeholder supported management plan for the fishery and describes its essential components. Section 4 presents findings from the survey and explains their significance and implications. Section 5 discusses the results along with policy implications, and section 6 draws the concluding remarks.

\section{Brief Description of the Fishery}

The Sultanate of Oman is located at the south-eastern corner of the Arabian Peninsula between latitudes $16^{\circ} 40^{\prime}$ and $26^{\circ} 20^{\prime}$ North and longitudes $051^{\circ} 50^{\prime}$ and $059^{\circ} 40^{\prime}$ East and has a coastline of about $3165 \mathrm{~km}$. It is bordered by three different water bodies: the Arabian Gulf, the Sea of Oman and the Arabian Sea (see Figure 1).

The fisheries sector in Oman has two distinct segments namely the traditional (or artisanal) and the industrial. About $96 \%$ of the total landings (2011 estimate) are from the traditional sector, and the traditional sector provides direct employment to 40,161 fishers [25]. The Ministry of Agriculture and Fisheries (MAF), is the responsible authority for the management of the fisheries resources and The Marine Fishing and Living Aquatic Resources Protection Law (MFLARPL) — which was issued in 1981 according to the Royal Decree number 53/8provides legal mandate for the conservation and exclusive management of the fishery resources within the country's territorial water (further details on the fisheries sector can be found in, for instance, [3] [26].

This section provides an overview of the ecological, biological, operational, socio-economic and institutional characteristics with particular reference to the kingfish fishery in Oman. It should be emphasized that the data and information presented in Table 1, and Figure 2 and Figure 3 have guided the goals and operational objectives of the plan and the set of potential "indicators", "management controls" and "management options" in the proposed management plan for the fishery.

Narrow-barred Spanish mackerel (Scomberomorus commerson) locally known as "kannad" or kingfish, is a

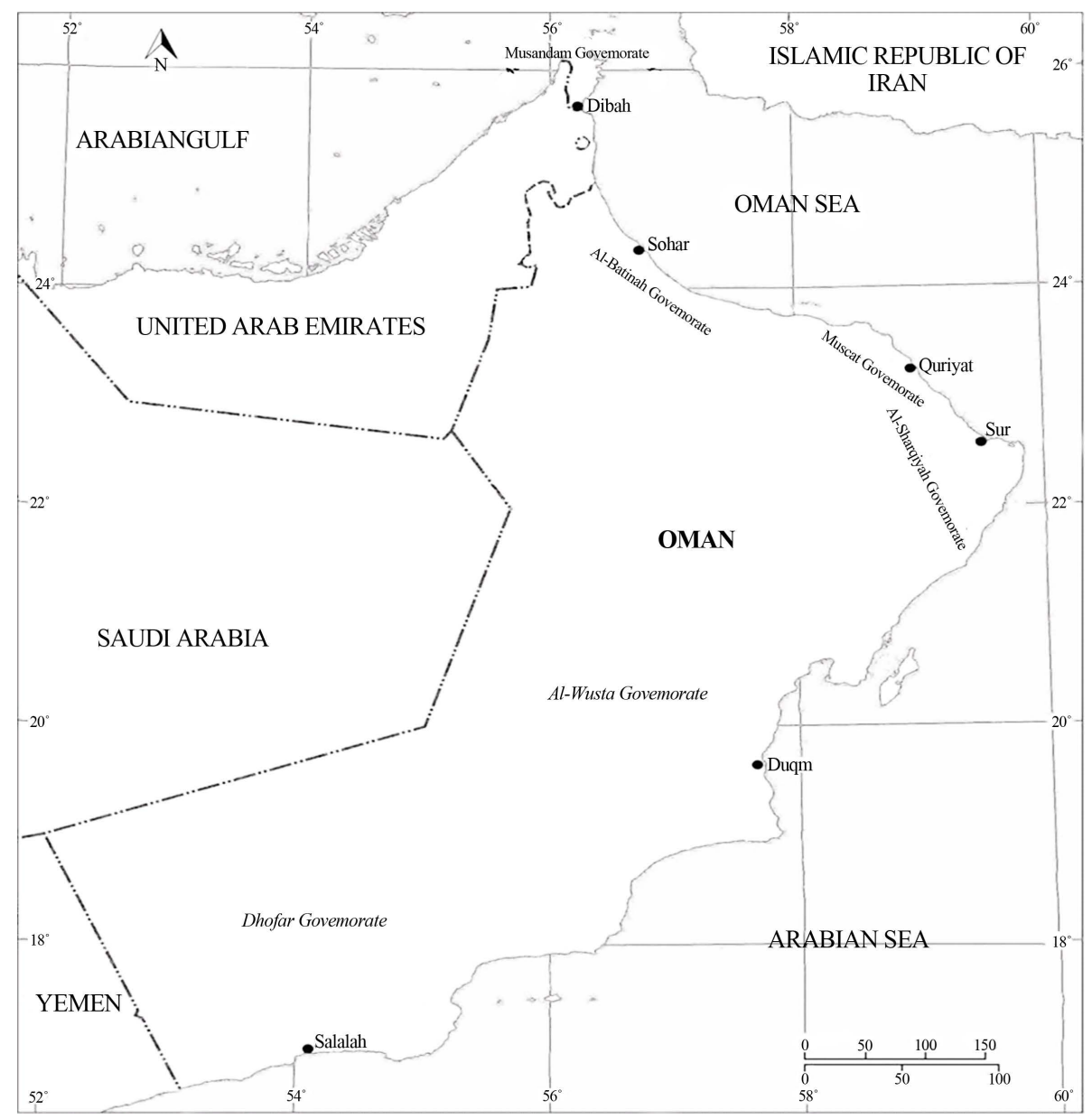

Figure 1. Map of the Sultanate of Oman including coastal Governorates. 
Table 1. Summary of the ecological and biological characteristics of Kingfish (S. commerson).

\begin{tabular}{|c|c|c|c|}
\hline Parameter & \multicolumn{2}{|c|}{ Local estimate/observation } & Source \\
\hline $\begin{array}{l}\text { Species } \\
\text { distribution }\end{array}$ & \multicolumn{2}{|c|}{$\begin{array}{l}\text { Along the coast of the Sultanate of Oman (Arabian Gulf, Oman Sea and Arabian Sea) from the } \\
\text { Musandam Peninsula in the north to Dhofar in the south. }\end{array}$} & [16] \\
\hline Depth range & \multicolumn{2}{|c|}{ Occurs in the water column less than $100 \mathrm{~m}$ in depth. } & [29] \\
\hline $\begin{array}{l}\text { Migration pattern of } \\
\text { species }\end{array}$ & \multicolumn{2}{|c|}{$\begin{array}{l}\text { During the summer months (May until August) kingfish appear to move northwards into the } \\
\text { Arabian Gulf from the eastern Arabian Sea and Indian Ocean. This movement is believed to be } \\
\text { for spawning, which lasts for a period of one to four months. The return journey of the spent } \\
\text { (maturity stage category) fish occurs by the end of summer. }\end{array}$} & [8] \\
\hline $\begin{array}{l}\text { Feeding } \\
\text { behavior }\end{array}$ & \multicolumn{2}{|c|}{$\begin{array}{l}\text { Feeds mainly in open water on small pelagic fish (e.g. sardines and anchovies), as well as on } \\
\text { invertebrates (e.g. squid) and feeding apparently takes place during the day and night. }\end{array}$} & [16] \\
\hline Catch size & \multicolumn{2}{|c|}{$\begin{array}{l}\text { Estimated between } 24 \text { and } 197 \mathrm{~cm} \text { fork length (FL), with the majority falling within the } 48 \text { - } \\
147 \mathrm{~cm} \text { fork length (FL). }\end{array}$} & [5] \\
\hline Maximum age recorded & \multicolumn{2}{|c|}{21 years for female \& no male older than 10 years } & [8] \\
\hline By-catch & \multicolumn{2}{|c|}{ Immature kingfish are caught together with other species } & [4] \\
\hline Size at first capture & \multicolumn{2}{|c|}{$\begin{array}{l}40-60 \mathrm{~cm} \text { fork length (FL) } \\
45 \mathrm{~cm} \text { fork length (FL) }\end{array}$} & [4] [7] \\
\hline Age at first capture & \multicolumn{2}{|l|}{4 - 6 months } & [4] \\
\hline Size at first maturity & \multicolumn{2}{|c|}{$\begin{array}{l}\text { Combined: } 75 \text { - } 80 \mathrm{~cm} \text { (FL) } \\
\text { Male: } 84.7 \mathrm{~cm} \text { fork length (FL) } \\
\text { Female: } 80.4 \mathrm{~cm} \text { fork length (FL) }\end{array}$} & [4] [27] \\
\hline $\begin{array}{l}\text { Age at first } \\
\text { maturity }\end{array}$ & \multicolumn{2}{|l|}{18 - 24 months } & [7] [27] \\
\hline Sex ratio & \multicolumn{2}{|c|}{$\begin{array}{l}\text { Male/Female: } 0.74 \text { (Oman Sea) } \\
\text { Male/Female: } 1.10 \text { (Arabian Sea) }\end{array}$} & [8] \\
\hline \multirow{4}{*}{ Mortality } & Z (Total Mortality) & Male: 0.892 year $^{-1}$ & \\
\hline & M (Natural Mortality) & $\begin{array}{l}\text { Male: } 0.490 \text { year }^{-1} \\
\text { Female: } 0.376 \text { year }^{-1}\end{array}$ & [9] \\
\hline & F (Fishing Mortality) & $\begin{array}{l}\text { Male: } 0.402 \text { year }^{-1} \\
\text { Female: } 0.534 \text { year }^{-1}\end{array}$ & \\
\hline & \multicolumn{2}{|c|}{$\begin{array}{l}\text { M (Natural Mortality): } 0.35 \text { year }^{-1}, 0.64 \text { year }^{-1} \text { and } 0.77 \text { year }^{-1} \text { (based on life-history para- } \\
\text { meters using three different estimation methods) } \\
\text { F (Fishing Mortality): } 0.5 \text { - } 0.6 \text { year }^{-1}\end{array}$} & [5] [10] \\
\hline Growth rate & \multicolumn{2}{|c|}{ Rapid up until 2 years of age } & [4] [7] \\
\hline $\begin{array}{l}\text { Spawning } \\
\text { season }\end{array}$ & \multicolumn{2}{|c|}{ Spawning period mostly from April to June. } & [8] \\
\hline $\begin{array}{l}\text { Spawning biomass } \\
\text { per-recruit (SBR) }\end{array}$ & \multicolumn{2}{|c|}{$\begin{array}{l}\text { SBR (at the current fishing } \\
\text { rates) as compared to a virgin } \\
\text { stock. }\end{array}$} & [9] \\
\hline
\end{tabular}

Note: Authors' own compilation.

member of the family Scombridae (mackerels, tunas, bonitos) and sub-family: Scombrinae. The Omani kingfish is distributed along the coast of Oman from the Musandam Peninsula in the north to Dhofar in the south (Figure 1). Although kingfish is generally caught throughout the year, an initial scrutiny of the monthly total landings indicates that kingfish catches are substantially higher in September through to early December with a smaller peak in landings in late February to April. However, a considerable decline has been observed during the summer months (May to August). Table 1 presents some important ecological and biological information about the species along with their source references.

Kingfish is harvested predominantly by traditional fishers using fiberglass boats (5 - 10 m) and large wooden dhows (around $20 \mathrm{~m}$ ) with the total landings from the fiberglass boats being larger than that from the dhows, merely because of their large numbers (about 93\%) in the fishery [27]. Five different types of fishing gear (hand 


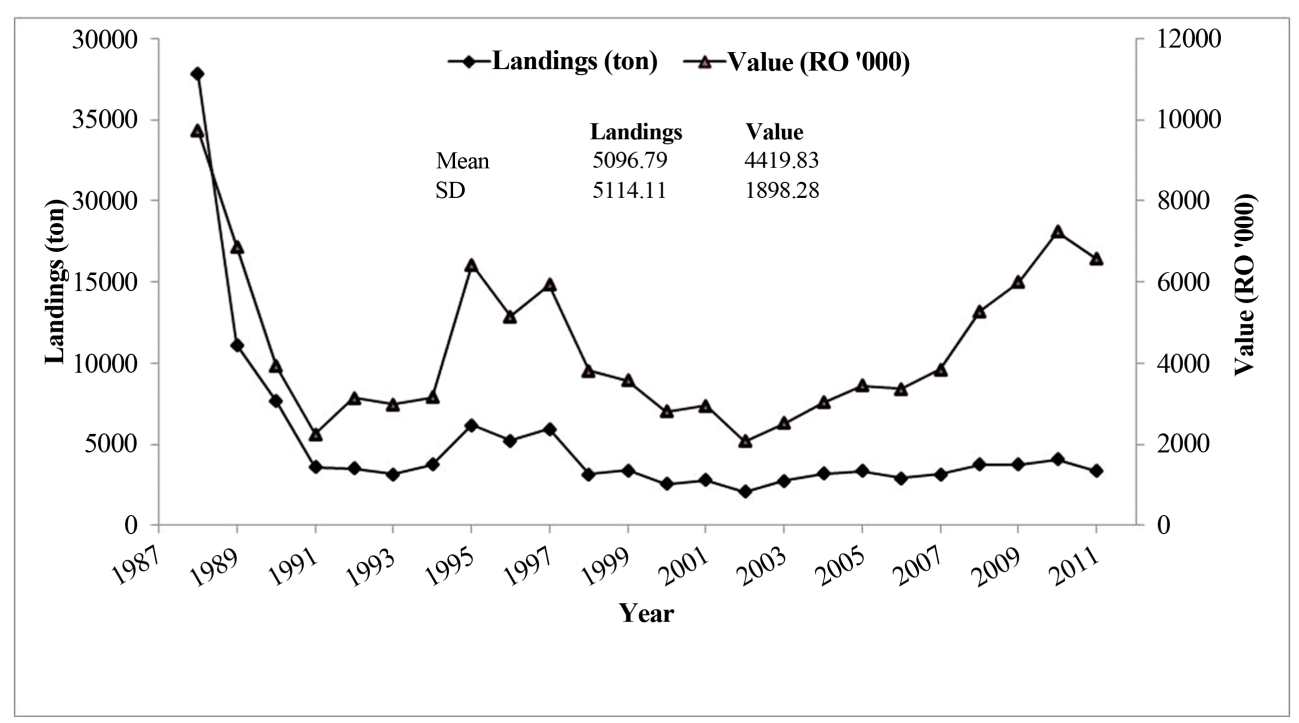

Figure 2. Landings (ton) and gross value (RO '000) of kingfish for the period 1988-2011. 1 Rial Omani $(\mathrm{RO}) \approx$ USD 2.59 .

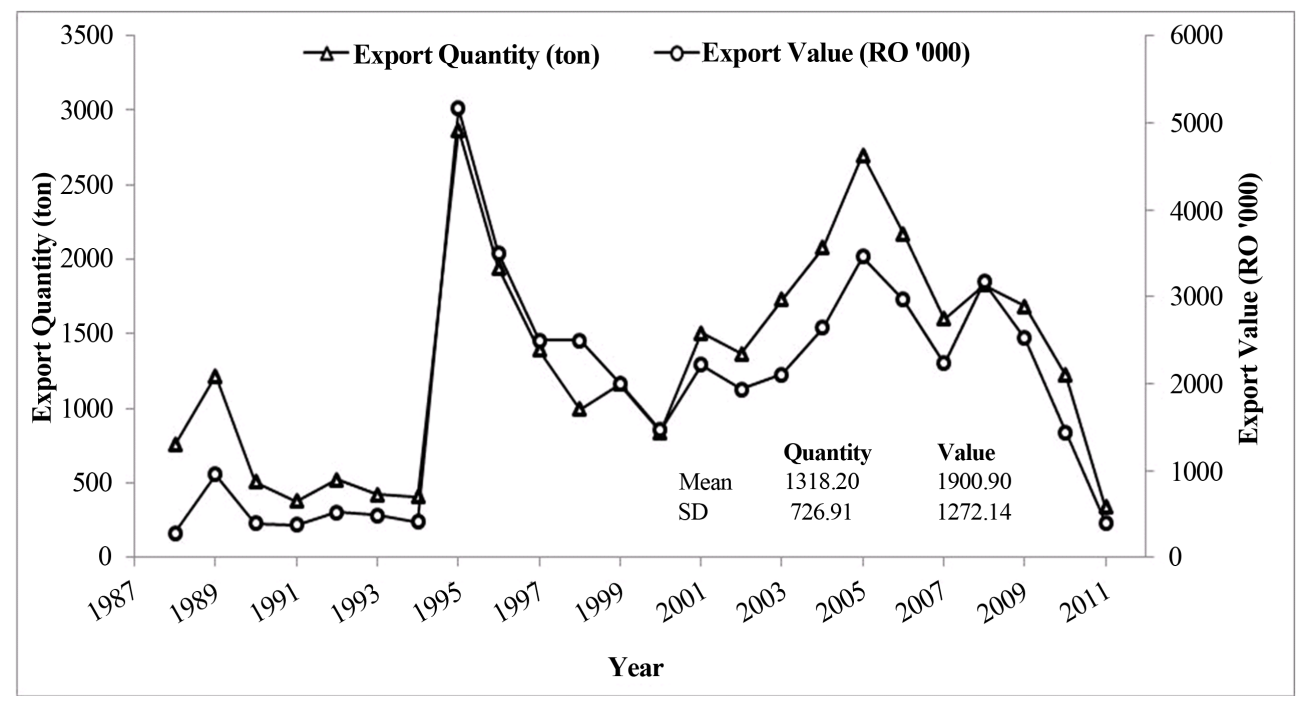

Figure 3. Export quantity (ton) and value (RO '000) of kingfish for the period 1988-2011.

lines with either live or dead bait, drift gillnet, set gillnet, beach seines, and longlines etc.) are common to the traditional sector [16] [28]. However, drift and set gillnets collectively account for approximately $75 \%$ of the gear types engaged in harvesting kingfish [27].

Figure 2 presents landings and gross value of landings of kingfish for the period 1988-2011. It is found that the landings of kingfish had experienced a considerable decline (about 88\%) during the period 1988 to 2011.

The coefficient of variation (CV) estimates for landings (100.34\%), total value (42.95\%) and unit value (34.2\%) of kingfish suggest that the variation in landings relative to unit price was the dominant factor contributing to the variation in the total value during 1988-2011. Even though the unit value for kingfish has experienced a positive trend, the extent of downward trend in landings over the period 1988-2011 resulted in legitimate concern as noted earlier for the management authority in relation to the economic viability and the long-run sustainability of the fishery. During the same period, the share of kingfish in the total large pelagic landings has dropped from about 37\% in 1988 to 8.4\% in 2011 (with the CV estimate of 53.63\%). These findings set limits on the formulation of economic goals and objectives for the fishery (see Table 4) and the associated management options. 
In the domestic market, kingfish is generally marketed whole and un-gutted. It is generally sold locally at landing sites or transported to local market places using refrigerated and non-refrigerated trucks. Kingfish is also exported to the Gulf Cooperation Council (GCC) countries. Statistical evidence suggests that the United Arab Emirates (UAE) and Saudi Arabia are the top export destinations (about 99.7\% of the total export quantity in 2011) [25]. Hence, kingfish plays an important economic role in foreign exchange earnings. Figure 3 presents the export quantity and total value of kingfish for the period 1988-2011.

The coefficient of variation (CV) estimates for the export quantity (55.14\%), export value (66.92\%) and unit value (32.93\%) for kingfish suggested that the variation in export quantity relative to unit value was the dominant factor contributing to the variation in total export value during 1988-2011.

\section{Methodology}

Given the time and costs constraints, it was decided to prepare a draft plan and communicate it to the intended stakeholder groups for their valuable inputs. It is important to note that the goals of the plan were guided by one of the key strategic goals (i.e. sustainable utilization of fisheries resources) of the $7^{\text {th }}$ Five-year Plan (2006-2010) for the sector. The operational objectives and targets are set up based on the existing scientific studies (see Table 1), five-year plans, and historical characteristics of the fisheries sector recorded in various project reports. The draft plan was also accompanied with a questionnaire for each stakeholder group to elicit their personal views on the various components of the proposed plan.

A face-to-face pilot survey was conducted involving six randomly selected fishers from Muscat and AlBatinah Governorates and nine representatives from non-fishers groups (six fisheries scientists and three fishery managers) to ensure full clarity of the questions and their relevance. The initial draft plan and the questionnaire were revised based on the minor remarks and comments (i.e. clarification of a few words) received from the respondents involved in the pilot study.

The final questionnaire had two distinct parts. The first part-which is group specific-contained questions in relation to the respondents' nature of involvement in the fishery, years of experience, level of education, awareness of management issues, views on the current biological status, views on the effectiveness of various communication modes, and preferences of management controls. As mentioned earlier, this type of information is important from a management perspective as it gives hint on the stakeholders' attitudes toward and perceptions about the fishery.

In contrast, the second part was common to both groups and attempted to obtain feedback on the following key elements: the adequacy of current legislative arrangements, management goals, operational objectives, performance indicators, proposed management measures and comprehensiveness of the proposed management plan. For instance, the respondents were asked whether a) the current legislative arrangements are sufficient enough for ensuring protection of the kingfish stock; b) the management goals identified in the draft plan are sufficient enough for ensuring long-term sustainability of the kingfish; c) the operational objectives stated under each goal in the draft plan are sufficient enough to achieve the overall management goals; d) the performance indicators identified under each operational objective are sufficient enough to evaluate the effectiveness of the management plan; and e) the management measures stipulated in the draft plan are sufficient enough for ensuring long-term sustainability of the kingfish fishery. A five-point scale was used with bi-polar adjectives, for instance, “1” represents highly sufficient and “5” represents not sufficient at all, to measure the views of the respondents.

Due to the professional diversity between the two groups and the level of educational attainment of the traditional fishers in general [22], the following methods were adopted in conducting the survey. For the secondary stakeholder group, a non-probability sampling technique (i.e. judgment sampling) was used and respondents were selected based on the trait of interest (research and managerial experience) they possessed. Next, the final questionnaire together with a draft plan, a brief overview of the various aspects of the fishery and the purpose of the survey were discussed in detail in a face-to-face interview and handed out to 43 participants during the period July-August, 2009. A total of 31 survey responses (a response rate of 72\%) were received. On the other hand, for the primary stakeholder group, a focus-group based interview approach was adopted to elicit the views of the respondents from each coastal Governorate. This type of interview approach for the primary stakeholder group was adopted to 1) initiate social interaction, 2) make fishers understand what was required of them, 3) explain the meaning of questions if such a need arose, and 4) motivate fishers to answer the questions in a simple and straightforward manner, among others. Six focus groups from six coastal Governorates (Musandam, 
Al-Batinah, Muscat, Al-Sharqyiah, Al-Wusta and Dhofar) were formed. On average there were eight members per focus-group, meaning a total of 48 fishers were interviewed. The participation in the interview was open to all fishers and an open invitation was made through the regional fisheries office. The attendance was dependent upon fishers' availability and willingness to participate in the survey. A convenient date and time was agreed to with the volunteer fishers and the interview occurred in places that were chosen by the fishers.

At the beginning of the focus-group interview, all members were welcomed together with a brief statement of the purpose of the survey, clear justification for the request for information along with the expected output from the survey, and a non-disclosure statement. To avoid any inappropriate use of survey information the respondents from both groups were kept anonymous following the code of conduct by the MAF. A single interviewer was involved in the focused interview to maintain consistency and standardize interviewer bias. A non-parametric statistical test $\left(\chi^{2}\right.$ test) was conducted to check whether there was a significant difference between the responses from the primary and secondary stakeholder groups with regard to the key elements of the proposed plan.

\section{Results}

\subsection{Respondent's Profile}

It was found that the average duration of involvement of the primary and secondary stakeholder groups in the fishery sector was 23.9 years and 15.6 years, respectively. It was noted that 44 out of 48 interviewed fishers were boat owners and the remaining were vessel crews. Twenty nine of the respondents from the fisher group were full-time fishers. With regard to the secondary stakeholder group, 22 respondents were fishery managers and 9 were fishery scientists. This is encouraging as it is expected that the efficacy of the proposed management plan would be scrutinized by the respondents based on their diverse professional experiences. It was also noted that 29 of the interviewed fishers were involved in the pelagic and demersal fisheries which suggests that the majority of artisanal fishers in Oman are involved in multi-species fishing activities. This finding is in line with other local study [22]. In a local study involving Al-Batinah Governorate, it was mentioned that the region's fishers were educationally challenged with a majority of them being illiterate [28]. In a sample of 100 fishers from two study areas (Barka and Al-Suwaiq), it was found that about 24 fishers had no education, 9 fishers could read and write, 43 fishers had primary level education, and the rest had secondary education [22]. This is consistent with the authors' observation during focus group interviews.

With regard to communication between stakeholder groups and the authority, it can be seen from Table 2 that "ministry notices" posted in various places (such as fishing ports and fish markets etc.), and "management meetings" were the best modes of communicating fisheries issues to both primary and secondary stakeholder groups respectively. Furthermore, the results also revealed that the role of mass media (such as, newspapers, television and radio) in creating awareness among fishers was perceived to be relatively minor. Although unexpected, the result indicates the diminishing role of the traditional institution called "Senat Al-Bahar (i.e. code of the sea)" in communicating fisheries issues with fishers. The same trend was observed by other studies [22] [28].

When asked about the "biological sustainability" of the kingfish stock there appeared to be a consensus among both stakeholder groups that the fishery is not biologically sustainable. Table 2 presents the results. This response is not unexpected as the situation is already revealed through scientific studies, and the fishers have already experienced a sharp decline in their catch shares over time. This particular situation demands urgent attention from the management authority to avoid the likelihood of a stock collapse in the future. It was also noted that about $21.4 \%$ and $7.1 \%$ of the non-fisher respondents perceived that kingfish stock was "probably" and "strictly" underfished, respectively. This perception is, perhaps, influenced by the fact that many local fishery managers have very limited exposure to scientific skills such as stock assessment comparable to their managerial competence that could limit their ability to assess the stock condition. Another possibility is that respondents' firmly held beliefs and/or professional interests cause them to disregard the prevailing scientific facts about the fishery.

The respondents were also asked to indicate their preferences to management measures under three broad categories namely, input, output and technical measures by using a scale ranging from 1 to 5, where " 1 " represents highly preferable and " 5 " represents not preferable at all. Table 3 presents the results. It can be seen that fishing effort controls (e.g. gear and vessel restrictions) and technical measures (e.g. area closures, seasonal closures etc.) were preferred to catch controls (e.g. total allowable catch). One reason may be that fishers are 
Table 2. Responses in relation to the mode of communication and the current status of the kingfish stock.

\begin{tabular}{|c|c|c|c|c|}
\hline \multirow{2}{*}{$\begin{array}{c}\text { Item } \\
\text { Communication media }\end{array}$} & \multicolumn{2}{|c|}{ Fisher $(N=48)$} & \multicolumn{2}{|c|}{ Non-fisher $(\mathrm{N}=31)$} \\
\hline & No. & $\%$ & No. & $\%$ \\
\hline Attend management meeting & 20 & 41.7 & 26 & 84.0 \\
\hline Ministry notice & 27 & 56.3 & 16 & 52.0 \\
\hline Newspaper & 4 & 8.3 & 7 & 23.0 \\
\hline Television/radio & 2 & 4.2 & 4 & 13.0 \\
\hline Personal contact with fishery managers & 5 & 10.4 & 14 & 45.0 \\
\hline Community leader (called “Wali”) & 19 & 36.9 & 0 & 0.0 \\
\hline Senat Al-Bahar committee (traditional institution) & 14 & 29.2 & 0 & 0.0 \\
\hline Scientific research & 0 & 0.0 & 19 & 61.0 \\
\hline \multicolumn{5}{|l|}{ Stock status } \\
\hline Severely overfished & 20 & 42.6 & 12 & 42.9 \\
\hline Just overfished & 22 & 46.8 & 8 & 28.6 \\
\hline Biologically sustainable & 4 & 8.5 & 0 & 0.0 \\
\hline Probably underfished & 1 & 2.1 & 6 & 21.4 \\
\hline Strictly underfished & 0 & 0.0 & 2 & 7.1 \\
\hline
\end{tabular}

Source: Field survey.

Table 3. Responses from both stakeholder groups regarding the preferred management measures.

\begin{tabular}{|c|c|c|c|}
\hline \multirow{2}{*}{ Management measures } & \multicolumn{3}{|c|}{ Mean scores* } \\
\hline & Fisher $(\mathbf{N}=48)$ & Non-fisher $(\mathbf{N}=31)$ & Overall \\
\hline Control of fishing effort (e.g. fishing gear, fishing method and vessel restrictions) & 1.4 & 2.0 & 1.7 \\
\hline Catch control (e.g. total allowable catch) & 3.5 & 3.0 & 3.3 \\
\hline Technical measures (e.g. area and seasonal closures) & 2.7 & 2.0 & 2.4 \\
\hline
\end{tabular}

Source: Field survey. *A five-point scale was used, where “1” represents highly preferable and “5” represents not preferable.

cautious about embracing total allowable catch (TAC) measure without having a clear idea of how will it work in the context of a shared stock. A second reason, perhaps, is the familiarity with the input control and technical measures because of their historical use. With particular reference to Oman, researchers have also recommended mesh size regulation [4] [9] and closed season [9] to control growth overfishing. Furthermore, based on a review of fisheries management in 32 different societies, it was found that all of the rules and practices were developed to control "how, when and where" fish were caught rather than "how many" fish were caught [30]. These measures were further discussed with the stakeholder groups and incorporated accordingly in the management plan (see Table 4). It is noted that there is no scientifically-based target reference point readily available for the fishery.

\subsection{The Elements of the Proposed Plan and Their Assessment by Stakeholders}

The key elements (i.e. goals, objectives, indicators and targets) of the stakeholder-approved plan are presented in Table 4.

As mentioned earlier in section 3, the key elements namely, the adequacy of current legislative arrangements, management goals, operational objectives, performance indicators, proposed management measures and comprehensiveness of the proposed plan were evaluated by stakeholders using a five-point scale where "1" represents highly sufficient/ very good and "5" represents not sufficient at all/not good at all. The results are presented in Table 5. Furthermore, recalling the expected differences in individual opinions stated in section 1 and following one of the objectives of the study, a null hypotheses $\left(\mathrm{H}_{0}\right.$ : there was no significant difference between the responses from the primary and secondary stakeholder groups) was tested using a non-parametric test $\left(\chi^{2}\right.$-test) based on the individual score and the corresponding results are presented in Table 5. 
A. H. Al-Balushi et al.

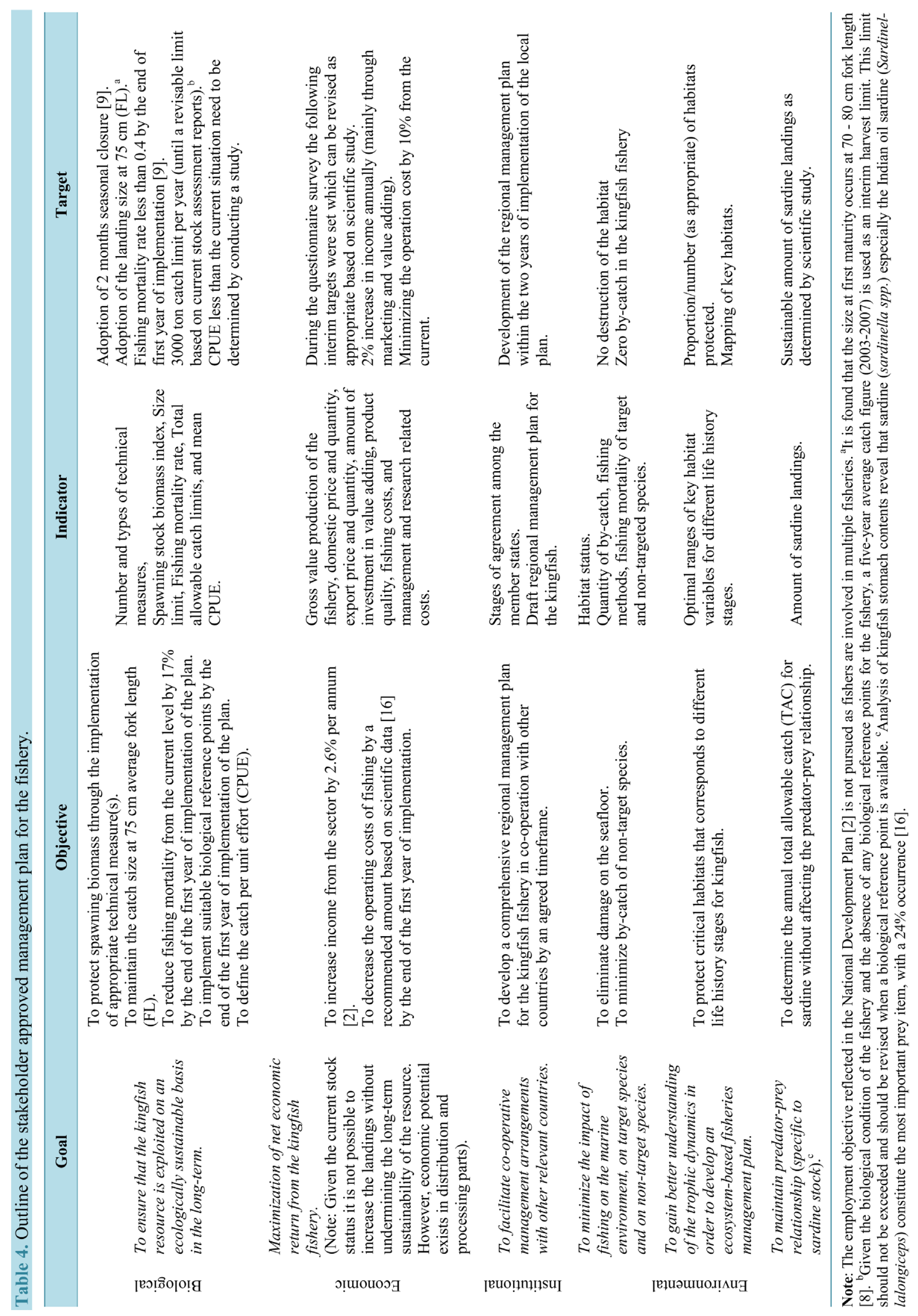


Table 5. Responses from both stakeholder groups regarding the key elements of the plan.

\begin{tabular}{|c|c|c|c|c|c|}
\hline \multicolumn{6}{|c|}{ Null hypothesis (Ho): There is no differences in responses of stakeholder groups (fisher and non-fisher) } \\
\hline \multirow{3}{*}{ Proposed plan elements } & \multicolumn{4}{|c|}{ Mean and highest frequency scores (HFS) ${ }^{1}$} & \multirow{3}{*}{ Test statistic: $\chi^{2}$ (df) } \\
\hline & \multicolumn{2}{|c|}{ Fisher $(\mathbf{N}=48)$} & \multicolumn{2}{|c|}{ Non-fisher $(\mathrm{N}=31)$} & \\
\hline & Mean & HFS & Mean & HFS & \\
\hline Current legislative arrangements & 4.7 & 4 & 3.7 & 3 & $24.793(3)^{*}(p$-value $=0.000)$ \\
\hline Management goals & 1.7 & 2 & 2.4 & 2 & $16.206(3)^{*}(p$-value $=0.001)$ \\
\hline Operational objectives & 2 & 2 & 2 & 2 & $19.884(2)^{*}(p$-value $=0.000)$ \\
\hline Performance indicators & 2 & 2 & 2.1 & 2 & $15.524(3)^{*}(p$-value $=0.000)$ \\
\hline Management measures & 2.3 & 3 & 2 & 2 & $13.483(3)^{*}(p$-value $=0.004)$ \\
\hline Overall management plan & 1.9 & 2 & 2 & 2 & $2.604(3)(p$-value $=0.457)$ \\
\hline
\end{tabular}

Source: Field survey. ${ }^{1}$ A five-point scale was used where "1" represents highly sufficient and "5" represents not sufficient at all. "Significant at the $5 \%$ level.

Table 6. Responses from fishers' group from six Governorates regarding key elements of the proposed plan.

\begin{tabular}{ccccccc}
\hline \multirow{2}{*}{ Plan elements } & \multicolumn{5}{c}{ Mean scores $^{*}$} \\
\cline { 2 - 6 } & Muscat & Al-Batinah & Musandam & Sharqiya & Al-Wusta & Dhofar \\
\hline Current legislative arrangements & 4.0 & 5.0 & 5.0 & 4.0 & 4.0 & 4.0 \\
Management goals & 2.0 & 1.0 & 2.0 & 2.0 & 2.0 & 2.0 \\
Operational objectives & 2.0 & 2.0 & 2.0 & 2.0 & 2.0 & 2.0 \\
Performance indicators & 2.0 & 2.0 & 2.0 & 2.0 & 2.0 & 2.0 \\
Management measures & 3.0 & 2.0 & 2.0 & 2.0 & 2.0 & 3.0 \\
Overall management plan & 3.0 & 1.0 & 2.0 & 2.0 & 3.0 & 3.0 \\
\hline
\end{tabular}

Source: Field survey. *A five-point scale was used where “ 1 ” represents highly sufficient and “ 5 ” represents not sufficient at all.

An interesting finding that can be noted from Table 6 is that there was no significant difference between the primary and secondary stakeholder groups with regard to the comprehensiveness of the proposed plan. However, despite the similarity in the highest frequency scores between the groups, there were significant differences between the groups with regard to other key elements of the proposed plan. This, perhaps, signals differences in individual knowledge, priorities and preferences attributable to the varying professional roles and responsibilities. The results may also provide an insight to the level of inadequacy of the current legislative arrangements to ensure protection of the kingfish stock. This is not unexpected as the effective management of shared resources is beyond the capacity of the national legislative arrangements which were mentioned during the focus group discussions.

With specific reference to the primary stakeholders an interesting question can be raised: are there any differences between individual focus groups with reference to the key elements of the plan? Considering the sample size of each focus group a descriptive statistical measure, such as mean score was used (instead of inferential statistical test) to indicate such likely differences between the focus groups. The results are presented in Table 6 .

One interesting finding was the similarity of the mean scores in relation to "current legislative arrangements" and their high values were consistent with the results presented in Table 6. With regard to operational objectives and performance indicators, it was noted that the mean scores were equal and lower than the scale mean (i.e. 3), which may indicate the level of adequacy of these elements. However, minor differences in mean scores were noticed in relation to "management measures" and the "overall management plan" which, perhaps, reflect the potential dissimilarities with respect to fishery characteristics, fishing operations, characteristics of fishing grounds, likely differences in socio-economic priority and biological and environmental issues among Governorates. For example, fishing operations in the Al-Wusta Governorate have been dominated by foreign crews, and 
hence the contractual arrangements for fishing operations are likely to differ. Although the use of a simple descriptive tool is not sufficient to explore the differences, it provides perspective for future research.

\section{Discussion and Policy Implications}

This section provides discussion and policy implications of the results. With regard to communication with the stakeholders on fisheries issues it was found that the role of mass media (such as, newspapers, television and radio) and the traditional institution locally called "Senat Al-Bahar" was perceived to be relatively minor. However, for initiating a change in fishing community attitudes and where illiteracy is an issue [22] [28], television and radio would be a logical and effective media. In addition, these modes have the potential to reach a wide range of the target stakeholders quickly and effectively. This type of campaign should also be adopted regionally to raise awareness among fishers and other relevant groups about the need for cooperative management of the fishery.

Considering the various positive aspects of co-operation as stated earlier, the management authority should search out possible ways to revitalize and nurture the role of the traditional institution and to create more responsible community attitudes towards resource use and rule compliance. At the national level, the authority could take essential steps to reform the traditional institution by establishing clearly defined roles for and responsibilities of the committee in relation to fisheries management. This action will not only provide an opportunity for the management authority to raise community awareness of fisheries issues, but also help reduce any communication gaps between the authority and the primary stakeholders. It is important to note that such approach focuses on disseminating conservation ethics through awareness programs and helps reduce local opposition to regulations. Of course, the effective solutions to the prevailing issues are likely to emerge over time through a learning process, however, inclusion and transparency in decision-making and, persistent dialogue with community leaders and members could help gain support from the local community. Also, stakeholders' consensus on "biological sustainability" of the stock and their keen interest in protecting the stock offer added rationale for cooperative action and collectively addressing the management issues facing the fishery.

The inadequacy of the current legislative arrangements as perceived by the stakeholder groups is not surprising as there has been a lack of comprehensive joint management arrangements with other countries that share the stock. This issue has also been raised in a number of regional workshops [12] [13]. In this context, and bearing in mind the disparity in country-specific fisheries situations, a slightly modified version of the management framework derived from Table 4 of this study was presented in the GCC workshop held in Muscat in February 2010 [31] to encourage the development of a co-operative management plan based on consensus. During the workshop, a working party amended the plan to reflect the respective local conditions and the amended plan was submitted for further consideration by the GCC Fisheries Authority within the GCC Secretariat and subsequently by the GCC Agricultural Committee. Furthermore, in September 3, 2014 the Ministry of Agriculture and Fisheries of Oman, has taken a Ministerial Decision (MD No. 2014/230) for the conservation and management of kingfish which comprises various articles under which seasonal restrictions (August 15 to October 15), size limits (length should be greater than or equal to $65 \mathrm{~cm}$ FL, as proposed in the amended plan during the GCC workshop held in Muscat in February 2010), trade restrictions (trading of kingfish is not allowed during closed season unless the catch is registered with the authority during the fishing season) and restrictions on fishing gear and methods (length of the hanging rope should not be more than $2400 \mathrm{~m}$, the depth of the net should not be greater than $10 \mathrm{~m}$ from the sea surface, mesh size should not be less than $95 \mathrm{~mm}$, twine use should not be less than $1 \mathrm{~mm}$ ) were stipulated. It was stated that the measures will enter into effect in 10 months from the date of issue of the decision. The issuance of this Ministerial Decision under the existing Marine Fishing and Living Aquatic Resources Protection Law - will help draw community and industry attention to the fishery. In line with the recommendation offered by the respondents, Oman should continue its proactive role in developing effective co-operative management arrangements with the Gulf Cooperation Council (GCC) countries to ensure the long term conservation of kingfish.

It was also suggested by the survey respondents that Oman should take a lead and raise the management issues pertaining to the conservation and management of kingfish stock in all regional events (for example, GCC meetings, Regional Commission for Fisheries (RECOFI) meetings, Indian Ocean Tuna Commission (IOTC) meetings) and encourage all member countries to design and implement an effective joint-management plan. In this regard, it is noted with optimism that the collaborative arrangements were also promoted in the FAO Work- 
shop on the "Status of Shared Fisheries Resources in the Northern Arabian Sea-Iran (Islamic Republic of), Oman and Pakistan”, held in Muscat, Oman, December 13-15, 2010 [13], and in the $8^{\text {th }}$ meeting of the Working Group on Fisheries Management under the Regional Commission for Fisheries (RECOFI) held in Egypt, December 8-10, 2014 [32]. However, an effort to harmonize national legislative arrangements of the relevant regional countries is necessary to ensure effective implementation of the cooperative-management measures. Furthermore, a possible mandate of establishing a "Kingfish Working Group" that could involve non-IOTC and non-RECOFI member nations has been proposed in the FAO Workshop on the "Status of Shared Fisheries Resources in the Northern Arabian Sea-Iran (Islamic Republic of), Oman and Pakistan” [13]. Reflecting on the geographical coverage and functional responsibilities of the existing regional organizations such as IOTC and RECOFI, the options for forming a new Regional Fisheries Management Organization (RFMO) for the Arabian Sea for management of particular marine areas, fisheries, and related marine environmental affairs were also considered in the same workshop [13].

Furthermore, the respondents revealed their concern about the extent of fisheries enforcement in the national context. Therefore, an attempt should be made to engage the fishing community to strengthen the existing enforcement and monitoring activities. Furthermore, persistence of an effective cooperation with the Royal Navy of Oman, the Royal Air Force of Oman, the Royal Oman Police and the Ministry of Manpower should be a priority when evaluating and re-designing annual enforcement plans at the national level. A land-based observer program should be fully supported and possibly enhanced at least in the short-run to ensure good enforcement of the law. However, in the long-run a cooperative enforcement arrangement will be required both at national and regional levels to make the enforcement program cost-effective.

Fishers' involvement in multiple fisheries should be kept in mind when adopting management measures that involve potential trade-offs between short-term socio-economic impacts on fishers and impacts on other fisheries resources through effort shift. In relation to the likely differences at the Governorate level as indicated from the results, it is recommended that the choice of management measures should be sensitive to local conditions and priorities to make them conducive to local conditions and thereby increase the legitimacy of regulations. In this context, fishery managers at the Governorate level should prioritize goals and decide on agreeable management measures to satisfy local preferences without compromising the sustainability of the stock.

In relation to the "operational objectives" and corresponding "performance indicators" as specified in the plan there were no significant differences noted between the stakeholder groups. In this context, various strategic actions were recommended by the stakeholders for consideration by the Ministry (see Table 4). For example, it is noted that a number of biological research projects are in operation however, their continuation as perceived by the groups is essential for monitoring the status of the stock. A joint monitoring program was also recommended at the FAO Workshop on the "Status of Shared Fisheries Resources in the Northern Arabian Sea-Iran (Islamic Republic of), Oman and Pakistan” [13].

It is important to note that the recommended measures of any sorts should not entice additional fishing efforts to the fishery that is already under pressure. To achieve greater confidence in the results an annual stakeholder forum (both national and regional) may be arranged by the authority to disseminate the findings to a larger group of key stakeholders, to debate appropriate national and regional policies and to reach broad consensus on the proposed measures. As kingfish is fished by traditional fishers from more than one nation, it may be desirable to establish a system of national quotas which is recently promoted by the IOTC (Resolution 14/02) for the conservation and management of tropical tunas stocks in the IOTC area of competence [31]-[33]. However, in [34] it was stated that "Scientists can calculate best estimates for stock abundance and optimal quotas corresponding to maximum yield or rent criteria, but the rational for implementing a particular management policy is often the outcome of complicated negotiations in the socio-political arena (p. 269)". The implementation uncertainty in catch and effort controls is also highlighted by others [35]. As no single authority by itself can solve the problem of overfishing, specific enabling legislation will be needed at both national and regional levels.

\section{Concluding Remarks}

This paper exemplifies a first-step towards the development of management options by involving key stakeholders that complement the current research agenda on the fishery. It is encouraging to note the overall rating on the comprehensiveness of the proposed plan by the key stakeholders. It is acknowledged that the results from this study may be constrained due to the small sample size particularly of the primary stakeholder. However, the 
researchers' own assessment from the focus group interviews indicates that the accumulation of new information was indeed a rare occurrence. This pattern is experienced by others [20] [22]. In this context, the findings of this paper may not be of limited importance as it is felt that a majority of issues and concerns that are common both nationally and regionally were captured by this study. Furthermore, it is exemplified that although views elicited in this study are partial in scope because of a single country-setting, the findings of this study in general, and the derived management plan in particular, have contributed in facilitating discussions and reaching consensus on the future course of action at the GCC workshop held in Muscat, February 2010. Finally, the subsequent action taken by the local Management Authority, as reflected by the Ministerial Decision (MD No. 2014/230), is a promising development. However, actions taken by one authority would not guarantee protection and conservation of the kingfish resource, it is hoped that this type of actions will resonate at the regional level in the near future to achieve long-term sustainability in the fishery.

\section{Acknowledgements}

The authors would like to thank two anonymous reviewers for their helpful comments. We also would like to thank all those who participated in the survey. The usual disclaimer applies.

\section{References}

[1] MNE (Ministry of National Economy) (2007) Long-Term Development Strategy (1996-2020): Vision for Oman’s Economy (Oman 2020), National Center for Statistics and Information, Muscat.

[2] MNE (Ministry of National Economy) (2007) Seventh Five-Year Development Plan 2006-2010, National Center for Statistics and Information, Muscat.

[3] Bose, S., Al-Mazrouai, A., Al-Habsi, S., Al-Busaidi, I. and Al-Nahdi, A. (2010) Fisheries and Food Security: The Case of the Sultanate of Oman. Proceedings of the International Conference on Food Security in the Arab Countries: New Challenges and Opportunities in the Context of Global Price Volatility, 2-4 March 2010, Sultan Qaboos University, Muscat.

[4] Dudley, R.G., Aghanashinikar, A.P. and Brothers, E.B. (1992) Management of the Indo-Pacific Spanish Mackerel (Scomberomorus commerson) in Oman. Fisheries Research, 15, 17-43. http://dx.doi.org/10.1016/0165-7836(92)90003-C

[5] Al-Hosni, A.H. and Siddeek, S.M. (1999) Growth and Mortality of the Narrow-Barred Spanish Mackerel, Scomberomorus commerson (Lacépède), in Omani Waters. Fisheries Management and Ecology, 6, 145-160. http://dx.doi.org/10.1046/j.1365-2400.1999.00134.x

[6] Al-Oufi, H.S., McLean, E., Goddard, J.S., Claereboudt, M.R. and Al-Akhzami, Y.K. (2002) The Kingfish, Scomberomorus commerson (Lacépède, 1800) in Oman: Reproduction, Feeding and Stock Identification, In: McLean, E., Al-Oufi, H.S., Al-Akhzami, Y.K. and Najamuddin, B., Eds., Contemporary Issues in Marine Science and Fisheries, Hasanuddin University Press, Makassar, 1-17.

[7] McIlwain, J., Claereboudt, M., Al-Oufi, H., Zaki, S. and Goddard, S. (2005) Biology of the Kingfish (Scomberomorus commerson) in the Coastal Waters of Oman, Part II: Spatial Variation in Age and Growth. Fisheries Research, 73, 283298. http://dx.doi.org/10.1016/j.fishres.2004.10.020

[8] Claereboudt, M.R., McIlwain, J., Al-Oufi, H.S. and Ambu-Ali, A. (2005) Patterns of Reproduction and Spawning of the Kingfish (Scomberomorus commerson, Lacépède) in the Coastal Waters of the Sultanate of Oman. Fisheries Research, 73, 273-282. http://dx.doi.org/10.1016/j.fishres.2005.02.009

[9] Govender, A., Al-Oufi, H.S., McIlwain, J.L. and Claereboudt, M.R. (2006) A Per-Recruit Assessment of the Kingfish (Scomberomorus commerson) Resource of Oman with an Evaluation of the Effectiveness of Some Management Regulations. Fisheries Research, 77, 239-247. http://dx.doi.org/10.1016/j.fishres.2005.08.010

[10] Ben Meriem, S., Al-Marzouqi, A. and Al-Mamry, J. (2006) Fisheries Exploitation Pattern of Narrow-Barred Spanish Mackerel, Scomberomorus commerson, in Oman and Potential Management Options. Applied Ichthyology, 22, 218224. http://dx.doi.org/10.1111/j.1439-0426.2006.00739.x

[11] Grandcourt, E., Al-Abdessalaam, T., Francis, F. and Al-Shamsi, A. (2005) Preliminary Assessment of the Biology and Fishery for the Narrow-Barred Spanish Mackerel, Scomberomorus commerson (Lacépède, 1800), in the Southern Arabian Gulf. Fisheries Research, 76, 277-290. http://dx.doi.org/10.1016/j.fishres.2005.07.001

[12] MAF (Ministry of Agriculture and Fisheries) (2010) Length-Based Fishery and Stock Assessment of the Kingfish, Scomberomorus commerson ((Lacépède, 1800) in the GCC Waters, Paper Presented at the Workshop on: The Management of Kingfish Fishery Resources in the GCC Countries, Muscat, 8-9 February 2010. 
[13] FAO (2011) Report of the FAO Workshop on the Status of Shared Fisheries Resources in the Northern Arabian Sea-Iran (Islamic Republic of), Oman and Pakistan, Muscat, Oman, 13-15 December, 2010, FAO Fisheries and Aquaculture Report No. 971, Karachi, 2011.

[14] UN (United Nations) (1982) The Law of the Sea. Official Text of the United Nations Convention on the Law of the Sea with Annexes and Tables. United Nations, New York, 1982, 224.

[15] UN (United Nations) (1995) Agreement for the Implementation of the Provisions of the United Nations Convention on the Law of the Sea of 10 December 1982 Relating to the Conservation and Management of Straddling Fish Stocks and Highly Migratory Fish Stocks. United Nations, New York, 1995.

[16] Al-Oufi, H.S., Claereboudt, M., Mcllwain, J. and Goddard, S. (2004) Stock Assessment and Biology of the Kingfish (Scomberomorus commerson: Lacepede) in the Sultanate of Oman. Ministry of Agriculture and Fisheries, Oman.

[17] Lélé, S.M. (1991) Sustainable Development: A Critical Review. World Development, 19, 607-621. http://dx.doi.org/10.1016/0305-750X(91)90197-P

[18] Mackinson, S. (2001) Integrating Local and Scientific Knowledge: An Example of Fisheries Science. Environmental Management, 27, 533-545.

[19] Hartley, T.W. and Robertson, R.A. (2009) Stakeholder Collaboration in Fisheries Research: Integrating Knowledge among Fishing Leaders and Science Partners in Northern New England. Society \& Natural Resources: An International Journal, 22, 42-55. http://dx.doi.org/10.1080/08941920802001010

[20] Bose, S. and Crees-Morris, A. (2009) Stakeholder's Views on Fisheries Compliance: An Australian Case Study. Marine Policy, 33, 248-253. http://dx.doi.org/10.1016/j.marpol.2008.07.004

[21] Pomeroy, R.S. and Berkes, F. (1997) Two to Tango: The Role of Government in Fisheries Co-Management. Marine Policy, 21, 465-480. http://dx.doi.org/10.1016/S0308-597X(97)00017-1

[22] Al-Subhi, K.K.N., Bose, S. and Al-Masroori, H.S. (2013) Fishers' Compliance Motivations: A Case Study of the Sultanate of Oman. Marine Policy, 37, 141-148. http://dx.doi.org/10.1016/j.marpol.2012.03.015

[23] Charles, A.T. (2001) Sustainable Fishery Systems. Blackwell Science Ltd., Oxford.

[24] Rice, C. (1993) Consumer Behavior: Behavioural Aspects of Marketing. Butterworth-Heinemann Ltd., Oxford.

[25] MAF (Ministry of Agriculture and Fisheries) (2011) Fishery Statistics Book, Fisheries Statistics and Information Department. General Directorate of Fisheries Research, Sultanate of Oman.

[26] Al-Balushi, A.H. (2010) A Management Plan for the Kingfish (Scomberomorous commerson, Lacépède, 1800) Fishery of the Sultanate of Oman. M.Sc. Thesis, Sultan Qaboos University, Muscat.

[27] Claereboudt, M.R., Al-Oufi, H.S., McIlwain, J. and Goddard, J.S. (2004) Relationships between Fishing Gear, Size Frequency and Reproductive Patterns for the Kingfish (Scomberomorus commerson Lacépède) Fishery in the Gulf of Oman. In: Payne, A.I.L., Obrien, C.M. and Rogers, S.I., Eds., Management of Shared Fish Stocks, Blackwell Science Ltd., Oxford, 56-67. http://dx.doi.org/10.1002/9780470999936.ch4

[28] Al-Oufi, H.S., McLean, E. and Palfreman, A. (2000) Observations upon the Al-Batinah Artisinal Fishery, the Sultanate of Oman. Marine Policy, 24, 423-429. http://dx.doi.org/10.1016/S0308-597X(00)00017-8

[29] Randall, J.E. (1995) Coastal Fishes of Oman. University of Hawaii Press, Hawaii.

[30] Wilson, J.A., Acheson, J.M., Metcalfe, M. and Kleban, P. (1994) Chaos, Complexity and Community Management of Fisheries. Marine Policy, 18, 291-305. http://dx.doi.org/10.1016/0308-597X(94)90044-2

[31] Bose, S. and Al-Balushi, A. (2010) A Management Framework for the Kingfish Fishery in the Gulf Cooperation Council (GCC) Countries, Paper Presented at the GCC Kingfish Workshop. Ministry of Fisheries Wealth, Muscat, 8-9 February, 2010.

[32] RECOFI (Regional Commission for Fisheries) (2014) Regional Joint Assessment of the Kingfish Stock in the RECOFI Area. 8th Meeting of the Working Group on Fisheries Management (RECOFI: WGFM8/2014/3), Cairo, 8-10 December 2014, 4 .

[33] IOTC (Indian Ocean Tuna Commission) (2015) Draft: Options for Interim Management Measures for Billfish in the Indian Ocean. Report Prepared by the IOTC Secretariat, WPB13-09, 17 August 2015.

[34] Getz, W.M. and Bergh, M.O. (1992) Quota Setting in Stochastic Fisheries. In: Wooster, W.S., Eds., Fishery Science and Management Objectives and Limitations: Lecture Notes on Coastal and Estuarine Studies, Vol. 28, American Geophysical Union, 259-277.

[35] Stefansson, G. and Rosenberg, A.A. (2005) Combining Control Measures for More Effective Management of Fisheries under Uncertainty: Quotas, Effort Limitation and Protected Areas. Philosophical Transactions of the Royal Society B: Biological Sciences, 360, 133-146. http://dx.doi.org/10.1098/rstb.2004.1579 